капитал, экономику и социальную сферу, от эффективности функционирования органов здравоохранения и успехов в развитии фундаментальной медицины.

Исследование выполнено в рамках государственного задания НИУ «БелГУ» на 2017 год, проект №28.7195.2017/БЧ «Риски и тренды самосохранительного поведения населения центтральных регионов Российской Федерациии

$* * *$

1. Данные Федеральной службы государственной статистики // Федеральная служба государственной статистики: офиц. сайт. - Режим доступа: http://www.gks.ru

2. Доклад о человеческом развитии в Российской Федерации за 2016 год. С. 11. // Аналитический центр при Правительстве Российской Федерации: офиц. сайт. - Режим доступа: http://ac.gov.ru/events/011075.html.

3. Звездина Н.В., Иванова Л.В. Ожидаемая продолжительность жизни в России и факторы, влияющие на нее // Вопросы статистики. - 2015. - № 7. - С. 10-20.

4. Население России 2014 : двадцать второй ежегодный демографический доклад / отв. ред. С.В. Захаров; Нац. исслед. ун-т «Высшая школа экономики», 2016.

5. Об утверждении Концепции демографической политики Российской Федерации на период до 2025 года : Указ Президента РФ от 09 октября 2007 г. № 1351 (ред. от 01.07.2014) // Справочно-правовая система «Консультант Плюс». Информ. банк «Версия Проф» Разд. «Законодательство».

6. Таблица данных ожидаемой продолжительности жизни при рождении в странах мира на 2016 год // Total-Rating.ru: Все рейтинги: сайт. - Режим доступа: http:/total-rating.ru/1840-ozhidaemayaprodolzhitelnost-zhizni-v-stranah-za-2016-god.html.

\title{
Sukhanova N.A. \\ Ethnological studies and adaptation in the cultural millieu
}

The Russian Presidential Academy of National Economy and Public Administration. (RANEPA)

(Russia, Moscow)

doi $10.18411 / g q-30-11-2017-20$

idsp 000001:gq-30-11-2017-20

\section{Abstract}

The article shows the ethnological approach to the problem of adaptation in a host country. Numerous scholars in the past exposed the phenomenon as a versatile compound of factors, which could be studied in its complexity with due account of a specific cultural environment.

Keywords: Ethnicity, living space, nation, natural resources,Passionarnost, biosphere, individual egoism, ethno genesis, psychological adaptation, recipient country, diffusion of cultures, emotions.

The frequent occurrence of the wordsethnicity and adaptation inthe world mass media does not mean the problem is under a scrupulous study and is about to be solved. Numerous flows of immigrants having infiltrated into Europe have given rise to a tremendous concern displayed within the public at large. Europe has always been the center of attraction for many ethnical groups, without mentioning individuals, coming in search for a better life, but the events of the past years have split the world community tremendously. Allowances, educational courses, warm welcoming do not seem to be of great help. The main question that might be justifiably asked is what do we want from immigrants and what do they want from us? Is the concern about the future of Europe really so alarming? As cultural adaptation was considered to be the main pillar in the structure comprisingmultiple cells of human activities, an approach to the challenges on the part of the ethnical turbulent issue, such issues as a change in geographical position, historical memory, forms of behavior, family traditions sometimes still remains in the shadow. 
Outstanding scholars displayed a variety of views on the problem of ethnicity, considering different factors of territory, confession, social facts, biosphere and etc. The If we skim through the publications made ethnologists, we might recall that there were theories admitting the existence of the countries with history and countries without history. Prehistoric societies, according to some ethnologists, might well be considered societies without culture, and at the same time there are societies or donor nations who could swallow cultures of minor ethnic groups and become at the same time a giant super ethnos, smaller nations would be like helping struts supporting the giant structure of an accumulator which swallows all the past and present knowledge of the world. We may speak about diffusion of cultures or merging cultural milieu, ignoring at the same time psychological problems or sense of psychological stress. It would be quite justifiably askedif geographyreallyplays a certain role in the lives of the migrants. According to his early works, FranzBoas understood geography as a background of history and in his research he tried to prove the existence ofthe coronary changes in generations that became evident ten years after their immigrant mothers came to live into the Untied States. This kind of evidence testifies that geographical position and climate do matter.His geographical determinism, however, gave way to a theory where he asserted that human culture is not an adaptation to nature. According to him, similarities and differences cannot be explained by geography alone. Boas asserted that differences in culture or similarities were to be explained by differences or similarities in racial factors, in geographical factors or in the stages of a progressive evolution.

The problem of borders, as limiting the living space, was highlighted in the works of Friedrich Ratzel. Space for Ratzel was rather a vague idea, but the Raum theory served as a driving force, and biological concept of geography presupposed that borders were a temporary stop in the organic growing of nations. The land in its spiritual bond with the people, feeds the nation from its natural resources, and it ismore important for a man than the state proper. Diffusion of cultures was understood as a part and parcel of human history and changes in cultures could be explained by mutual borrowing. According to him, cities are the best place to study human beings because life in the city is "blended, compressed and accelerated". But he considered lives in the cities located mostly in the USA: New York, Washington, San Francisco, Boston. According to Ratzel the expansion of a state's borders could be called a reflection of the nation's health. The survey of the most of the anthropologists' works shows, however, that they deny the fact that a territorial factor fastens ethnos together.

In numerous questions such as to what keeps the nation as such and maintains its integrity, the issue of collective consciousness stands high. There is such a thing as emotional mood, or an idea common for the whole of the nation, that does not allow the nation to split apart. It could happen in the event of apatriotic war, when the fight against the common enemy imparts the stimulus to unite. The fall in "Passionarnost", according to Lev Gumilyov, resulted in a diminishing unity and the increased pursuit of short-term interests over the longterm goals. Gumilyov saw human behavior in its ethnic aspect as part of biosphere. Ethnogenesiswas a natural, spontaneous and long-term process independent of conscious acts. As we, however, take a glance at the present day kaleidoscope of controversial ideas related to the issue of diffusion of cultures, people who been living in Europe, would hardly say that waves of disengagement sprang up due to the lack of Passionarnost or a fight against the common enemy.

William James understood emotion in terms of a sequence of events that starts with the occurrence of an arousing stimulus and ends with a passionate feeling, a conscious emotional experience. According to him, a major goal of emotion research is still to elucidate this stimulus-to-feeling sequence, to figure out what processes come between the stimulus and the feeling. According to James, emotions feel different from other states of mind, an emotion is the mind's perception of psychological conditions that result from some stimulus. 
As Emile Durkheim wrote, the emotional part of the collective consciousness overrides the individual egoism. According to him, cultural diversity is overruled by more powerful and significant force as overall cultural system of beliefs and customs and law and order. In the present circumstances within the extreme population density and the more sophisticated system of the state-of- the-art technologies, the social interaction seems to be of no help. Weeks of euphoriaexperienced within the days when the cherished dream of newcomers comes true, are followed by a sudden sadness or even a feeling of stress, as the reality appears to be quite the opposite one from what they expected.Psychological adaptation turns out to be the greatest of all the turmoil.

A common labor, collaboration of skills, could become the most powerful driving force, a uniting force of educated and trained residents.But it is confrontedwith such pitfalls as poor language knowledge, or its absence, adaptation to the rules of behavior at work or absence of skills in the approach to working conditions, which are evident for local population and could be taken as accepted norms from the childhood and from what is inspired in the European family circles, but are found to be alien and cause counteraction among immigrants.According to a report issued by the European Commission under the name Indicators of Immigrant Integration 2015, the research has shown that immigrants with low or no qualifications are more likely to run into problems of language or knowledge of the host country's culture, which are important for obtaining the citizenship.

There could be a short-term problem when refugees come from a war-torn country. It would be absurd to require a very quick adaptation to the existing rules and ethics of the recipient country, because that is a problem of survival for them. Another thing is when immigrants come in search for a better life and their enthusiasm gives them a hope to become a full-fledged citizen. In that case the sense of ignorance of the host culture values could turn out to be a tragedy. Sociologists assume several steps on the way of the immigrant adaptation. In some cases it works, and in turn of depression there comes the pacification and tranquility. But in some cases not. Ethnic groups alienate from the host society, distancing from any kind of permanent work, living on allowances that the host country gives them. The factor of labor unity and cohesion that is called upon to unite society, goes into oblivion. Ethnic groups, newcomers, stick to separatists ideas, time and again giving rise to heated debates and violent gatherings.

Some years in the past witnessed the enthusiasm on the part of ethnologists who used to travel to remote areas in Africa, Asia, North Canada, Oceanic islands and etc. They hadn't not got thecomplete accesses to correct information about the aboriginal population until they settled firm ties with the local people, or found informants, who served as agents who provided the ethnologists with verified data as to the life style and moral requirements of the natives as the level of the scholars' knowledge of the local people was not enough at that time . Long-time travelling and living in the aboriginal territories for years allowed the researchers to come to know better the local peculiarities and exist in the alien environment quite peacefully.BronislavMalinowski, who displayed highly methodical and well theorized approach to the study of social systems, emphasized the importance of detailed participant observation and believed that anthropologists must have daily contact with their informants in the native areas as they are to adequately record the imponderabilia of everyday life, which is very important in their efforts to penetrate into the local culture.

The fundamental problem of a turbulent society has always been and still remains the problem of man. As N.A. Berdyaev wrote, man is microcosm and microtheos. Manis created in the image and likeness of God, but at the same time man is a natural being. Spiritual insights of a man do not rest either on surrounding milieu or society. That freedom that lives in the man is the freedom uncreated and primordial. While the creative force developing in a man finds its objectivism in culture, technological civilization could easily transform a man into a function. According to Berdyaev, in the present -day world a man is in search of a product more than a cultivation of ideas. 
At the same time Sir Edward Burnet Tylor asserted that human mind and its capabilities are the same across the globe, irrespective at whatever stage a certain society is placed at a given moment in social revolution. In other words the primitive society has the same intelligence potential as in the developed modern world. The crux of the matter lies in education. According to Tylor, cultural differences exist due to different stages in the nations development.As for Alfred Radcliffe-Brown, he asserted that what is needed for the world is to create new practices and they must not conflict with social practices and the practices would grow and support each other, that could be called co-adaptation. Lev Gumilyov keynoted the behavioral nature of ethnos. According to Lev Gumilyov, civilization is using the results of the culture, while the culture is the movement through hundreds of centuries and thousands of generations.

Sociocultural elements which comprise behaviors, values, attitudes, beliefs, confession, demographic peculiarities, based on geographical location of the host country present such a complicated bundle of elements that must be studied in its full complexity without ignoring a single part of it. According to Durkheim a social fact must always be studied according to its relation with other social facts rather than to an individual.

Of course, no biased attitude must be admitted.According to LeoFrobenius cultural elements must be studied in more complex context within their culture. No matter what other factors might come to the fore of the problem, the evident feature that could unite the different layers of the population are the nuclear family ties and education, and what we could understand by family ties are the ties of the second circle or ties between relatives and the society based on respect towards each other.Self-consciousness is mentioned in a number of research works as a strong identifying factor. As far as the education is concerned, psychological factor is of great importance, where teachers and lectures could attract the attention of the audience by showing the knowledge of the culture of incomers, by comparing methods and historical facts, by introducing the elements of the mode of life of migrant circles at the very first stages of education, completing the further steps in the education by more advanced technique and knowledge of the present day world.

$$
\text { *** }
$$

1. Berdyaev, N.A. My Philosophic World-Outlook. - Pro and Contra, 1994

2. Bromley, Y.U. Essays on the theory of ethnos. - Moscow State university, 1993

3. Franz Boas. Anthropology and modern life. Dover Publications, Inc. New York, 2015.

4. Gumilyov, L.N. Ethnosphere: History of people and history of nature. - Moscow, 1993

5. Malinowski, B., R.J. Thornton \&Skalnik, ed. The early writings. Cambridge University Press, 1993

6. Putman, R.A. The Cambridge Companion to William James. Cambridge University Press, 1997

7. Migration and cultural integration in Europe. Conference report. Brussels, December 2013.

8. Indicators of Immigrant Integration 2015: Setting in. OECD/European Union (2015). OECD Publishing, Paris. 